Published in final edited form as:

Cryst Growth Des. 2016 July 6; 16(7): 3838-3845. doi:10.1021/acs.cgd.6b00384.

\title{
Characterization of Protein Nanocrystals Based on the Reversibility of Crystallization
}

\author{
Katerina Dörner ${ }^{\dagger, \ddagger, \#}$, Jose M. Martin-Garcia ${ }^{\dagger, \ddagger, \|}$, Christopher Kupitz ${ }^{\dagger, \perp}$, Zhen Gong ${ }^{\dagger, \ddagger, \nabla}$, T. \\ Conn Mallet ${ }^{\S}$, Liqing Chen ${ }^{\dagger, \ddagger}$, Rebekka M. Wachter ${ }^{\dagger, \ddagger}$, and Petra Fromme ${ }^{*}, \dagger, \neq, \|$ \\ †School of Molecular Sciences, Arizona State University, Box 871604, Tempe, Arizona 85287, \\ United States \\ $\neq$ Center for Membrane Proteins in Infectious Diseases (MPID), Arizona State University, Box \\ 871604, Tempe, Arizona 85287, United States \\ $\S$ Life Science, Rigaku Americas Corporation, 9009 New Trails Drive, The Woodlands, Texas \\ 77381, United States \\ "Center for Applied Structural Discovery, The Biodesign Institute, Arizona State University, PO Box \\ 875001, Tempe, Arizona 85287, United States
}

\section{Abstract}

\begin{abstract}
A new approach is described to screen for protein nanocrystals based on the reversibility of crystallization. Methods to characterize nanocrystals are in strong need to facilitate sample preparation for serial femtosecond X-ray nanocrystallography (SFX). SFX enables protein structure determination by collecting X-ray diffraction from nano- and microcrystals using a free electron laser. This technique is especially valuable for challenging proteins as for example membrane proteins and is in general a powerful method to overcome the radiation damage problem and to perform time-resolved structure analysis. Nanocrystal growth cannot be monitored with common methods used in protein crystallography, as the resolution of bright field microscopy is not sufficient. A high-performance method to screen for nanocrystals is second order nonlinear imaging of chiral crystals (SONICC). However, the high cost prevents its use in every laboratory, and some protein nanocrystals may be "invisible" to SONICC. In this work using a crystallization robot and a common imaging system precipitation comprised of nanocrystals and precipitation caused by aggregated protein can be distinguished.
\end{abstract}

\section{Graphical abstract}

\footnotetext{
"Corresponding Author: Address: School of Molecular Sciences, Center for Applied Structural Discovery at the Biodesign Institute, Arizona State University P.O. Box 85287-1604 Tempe, AZ 85287-1604, USA. Phone +1 (480)-965-9028. Fax: +1 (480)-965-2747. pfromme@asu.edu. Web: http://www.public.asu.edu/ pfromme/.

\#Present Addresses: Center for Free-Electron Laser Science, Deutsches Elektronen-Synchrotron DESY, Notkestraße 85, 22607 Hamburg, Germany.

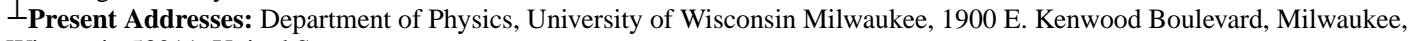
Wisconsin 53211, United States.

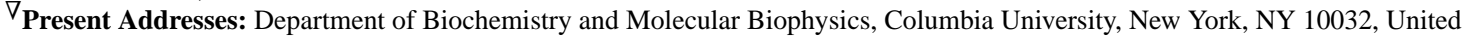
States.

Notes

The authors declare no competing financial interest.
} 


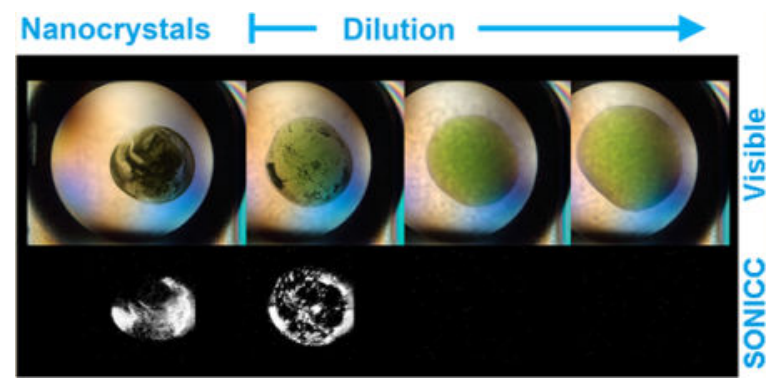

\section{INTRODUCTION}

X-ray crystallography is the most applied method for structural analysis of proteins. Ninety percent of protein structures deposited in the protein data bank (PDB) were solved by this technique. Common X-ray structure analysis requires the growth of protein macrocrystals, which are in most cases $50 \mu \mathrm{m}$ or larger. In recent years with the development of microfocus X-ray beams, structural analysis of protein microcrystals with dimensions down to 5-10 $\mu \mathrm{m}$ was achieved. ${ }^{1-3}$ The novel approach of serial femtosecond crystallography (SFX) using an $\mathrm{X}$-ray free electron laser (XFEL) allows the structural analysis of protein nanocrystals, which are in the range of $100 \mathrm{~nm}$ to $10 \mu \mathrm{m} .{ }^{4-8} \mathrm{SFX}$ is a high-performance technique to study the structure and dynamics of challenging proteins such as membrane proteins, which in many cases even after enormous effort do not lead to the growth of macrocrystals. ${ }^{9,10}$ The need for new methods to solve membrane protein structures is evident from the numbers of structures in the protein data bank (PDB). From more than 100000 structures deposited in the PDB less than 2000 entries are structures of membrane proteins, and less than 600 deposits are unique membrane protein structures. ${ }^{11}$ This lack of knowledge on membrane protein structures is in strong contrast to their frequency and importance: $25-30 \%$ of proteins in the genome in all living species are predicted to be membrane proteins, and 40$60 \%$ of drug targets are membrane proteins. ${ }^{12-14}$

In addition, SFX is a powerful technique to overcome the radiation damage problem in Xray crystallography by the "diffraction before destruction" principle and enables timeresolved studies in protein crystals. ${ }^{4,10,15-21}$ It is discussed in the literature that nanocrystals may have less structural defects than large size crystals. ${ }^{10,22}$ However, it has also been discussed that nanocrystals may show a decrease in order, as most molecules are at the surface and consequently involved in fewer crystal contacts. It was suggested that errors in the crystal lattice poison the surface and therefore prevent further growth of the crystal. ${ }^{10,23,24}$

An additional field for the application of nanocrystals is the structural analysis of proteins by solid-state NMR. ${ }^{25,26}$ Solid-state magic-angle spinning NMR spectroscopy on crystalline samples was successfully used to solve the structure of membrane proteins. ${ }^{27,28}$ One example is the transmembrane domain of the protein YadA, a trimeric autotransporter adhesion. In previous studies YadA macrocrystals only led to low resolution X-ray diffraction data. From the same preparation microcrystalline needles with a length of 5-10 $\mu \mathrm{m}$ were obtained enabling the structure determination by solid-state NMR. ${ }^{28}$ 
While microcrystals ( $>1 \mu \mathrm{m}$ ) can be detected by bright field microscopy, nanocrystals $(<1$ $\mu \mathrm{m})$ are too small to be detected with an optical microscope, and hence crystal growth cannot be monitored with common imaging methods used in crystallography. To cope with the high demand of nanocrystals for structural and functional analysis at present and in the future methods are needed to enable high-throughput screening. Techniques for the detection of nanocrystals are also valuable in conventional crystallography. Conditions leading to nanocrystals can be used for fine screening, and nanocrystals can serve as seeds for the growth of large crystals.

A powerful technique to screen for nanocrystals is second order nonlinear imaging of chiral crystals (SONICC). This method is based on the principle of second harmonic generation (SHG) and detects non-centrosymmetric crystals of chiral molecules such as proteins. ${ }^{29,30}$ SHG microscopy is routinely used to visualize proteins in an ordered scaffold such as in tissues and biological membranes. ${ }^{31}$ The commercially available SONICC instrument (Formulatrix Inc.) relies on the same principle and is a user-friendly setup with the focus on protein crystals. Crystals of proteins lead to a positive SONICC signal, whereas nonordered protein in solution or in the denatured state does not. Most salts are nonchiral; therefore most salt crystals are centrosymmetric ordered and do not produce a SONICC signal either. Furthermore, SONICC is complemented by ultraviolet two-photon excited fluorescence (UV-TPEF). SONICC active salt crystals lead only to a negligible signal with UV-TPEF and in this way can be distinguished from protein crystals. ${ }^{30,32}$ Signal intensity of protein crystals depends on many factors such as crystal symmetry class, crystal size, protein size, and secondary structure elements. ${ }^{33}$ As highly $\pi$-conjugated systems lead to a signal enhancement of second harmonic generation, the cofactor content and bound substrates also affect the strength of the signal. ${ }^{31,34,35}$ Therefore, SONICC is a high performance method for proteins containing chromophoric cofactors as for example chlorophylls or heme groups, proteins with bound aromatic substrates, and proteins fused to a GFP. However, for some nanocrystals of noncolored proteins the SONICC signal may be too low, and therefore they are not detectable in the screening mode of the instrument.

Recently it was reported that a novel protein microcrystal screening system was developed using X-rays at the BL32XU beamline at SPring-8 in Japan. ${ }^{36}$ They describe a trial experiment in which protein microcrystals smaller than $10 \mu \mathrm{m}$ were detected using lysozyme as a test protein. Standard SBS-format crystallization plates were mounted, and a whole well area could be screened within a minute. In addition, they briefly mention the development of a method to detect protein microcrystals by fluorescence. Crystals were visualized by postcrystallization soaking with fluorescence labels. ${ }^{36}$

In this work a different approach for the detection and screening of protein nanocrystals was investigated based on the reversibility of crystallization. The principle of recrystallization is a valuable approach for protein purification and is used in our laboratory as a last step of membrane protein purification. ${ }^{10}$ The concept was transferred to nanocrystallography with the idea that nanocrystals may dissolve after diluting the reservoir solution of the crystallization experiment, while denatured protein does not. The experiments show that with this procedure the distinction of precipitate consisting of nanocrystals and precipitate consisting of denatured protein is possible by using a conventional light microscope. High- 
throughput screening of conditions is enabled with the use of the Rigaku Phoenix crystallization robot and a common imaging system. In this study the membrane protein Photosystem I with internal chromophores, the Francisella tularensis membrane protein CapA fused to a GFP-tag and the soluble GFP protein variant mGFPsol were used as model systems. ${ }^{37-41}$ Using these protein preparations with internal chromophores or bound GFP variants, respectively, enables reliable monitoring of the experiments with SONICC. In 90\% of the cases where dissolution of precipitate after the dilution procedure was observed the precipitate indeed consisted of nanocrystals.

\section{MATERIALS AND METHODS}

\section{Protein Purification}

The membrane integrated CapA protein from $F$. tularensis fused to the folding reporter frGFP (CapA-frGFP) was purified as described previously. ${ }^{39}$ Briefly, the fusion protein was expressed using the Escherichia coli strain BL21 (DE3). Cells were sonicated, cytosolic membranes were isolated by high speed centrifugation, and membrane proteins extracted using $1 \% \beta$-DDM. CapA-frGFP was further purified by Ni-NTA affinity chromatography. After size exclusion chromatography as a last purification step CapA-frGFP in $20 \mathrm{mM}$ HEPES $\mathrm{pH} 7.0,300 \mathrm{mM}$ sodium chloride with $0.05 \% \beta$-DDM was concentrated (Amicon Ultra-15 Centrifugal Filter Devices, $100 \mathrm{kDa}$ cutoff, Millipore) to a protein concentration of $14 \mathrm{mg} / \mathrm{mL}$. This protein solution was then used for high-throughput crystallization experiments.

Photosystem I (PSI) from Thermosynechococcus elongatus was purified as described previously. ${ }^{37}$ Briefly, thylakoid membranes isolated from lysed cell cultures of the cyanobacterium were incubated in $0.6 \% \beta$-DDM to solubilize membrane proteins. PSI was further purified using anion-exchange chromatography. The column was equilibrated in 20 $\mathrm{mM}$ MES, $\mathrm{pH} 6.4,50 \mathrm{mM} \mathrm{MgSO}_{4}$ with $0.02 \% \beta$-DDM, and protein fractions were eluted by a salt gradient of $\mathrm{MgSO}_{4}$ with the PSI trimer eluting at $140 \mathrm{mM}$ salt concentration. The fractions were combined and concentrated to a chlorophyll concentration of $10 \mathrm{mM}$ and diluted with buffer without salt to a $\mathrm{MgSO}_{4}$ concentration of $6 \mathrm{mM}$. In this step PSI was precipitated in the form of small crystals. For further crystallization experiments the small crystals were completely dissolved in $5 \mathrm{mM}$ MES, $50 \mathrm{mM} \mathrm{MgSO}_{4}, 0.02 \% \beta$-DDM, pH 6.4 to a final protein concentration of $20 \mathrm{mg} / \mathrm{mL}$. To minimize exposure to room light, the purification was conducted under dim green light in a dark room.

The GFPlike protein mGFPsol was purified as described previously. ${ }^{40,41}$ To obtain native folded protein Escherichia coli cells were grown at $25^{\circ} \mathrm{C}$. The cytosolic fraction was applied to a Ni-NTA affinity column and mGFPsol was eluted with $500 \mathrm{mM}$ imidazole in $50 \mathrm{mM}$ HEPES pH 7.9, $50 \mathrm{mM} \mathrm{NaCl}$, and $1 \mathrm{mM}$ DTT. After dialysis in $50 \mathrm{mM}$ HEPES, $20 \mathrm{mM}$ $\mathrm{NaCl}, \mathrm{pH} 7.9$ the protein solution was concentrated to a protein concentration of $20 \mathrm{mg} / \mathrm{mL}$ (Amicon Ultra-15 Centrifugal Filter Devices, $10 \mathrm{kDa}$ cutoff, Millipore) and then used for crystallization experiments. 


\section{Crystallization Experiments and the Dilution Procedure}

Protein crystallization experiments were set up using the vapor diffusion technique (sittingdrop method) and 96-well plates (MRC 2 Well Crystallization Plate (Swissci), Hampton Research) with the crystallization robot Phoenix HT (Rigaku). Protein and reservoir solution were mixed in 1:1 and 2:1 ratios (total drop volume $200 \mathrm{~nL}$ and $300 \mathrm{~nL}$, respectively). The reservoir volume was $50 \mu \mathrm{L}$. For CapA-frGFP and PSI the following crystallization screens from Hampton Research were used: Index HT (HR2-134), MembFac HT (HR2-137), Natrix HT (HR2-131), and PEG/Ion HT (HR2-139). mGFPsol was screened using Crystal Screen HT (HR2-130), Index HT (HR2-134), Natrix HT (HR2-131), and PEG/Ion HT (HR2139), all from Hampton Research. For PSI and mGFPsol light exposure was minimized by using the robots light as the only light source in the room. Afterward plates were incubated at $20^{\circ} \mathrm{C}$ in the dark. Crystal growth was monitored using the imaging system of the SONICC benchtop instrument (Formulatrix, USA) recording pictures at visible light and in SONICC mode.

After 10-14 days (depending on the protein) the following dilution procedure was performed. The crystallization robot Phoenix HT (Rigaku) equipped with a specialized computer program (which will be available from Rigaku on request after publication) was used to remove $25 \mu \mathrm{L}$ of the reservoir solution followed by the addition of $25 \mu \mathrm{L}$ of ultrapure water. In between, the syringe tips were cleaned with water. For each 96-well plate the whole procedure including removal of the plate seal and resealing was completed within 2 min to prevent dehydration of the drops. The dilution step was performed three times in total in 3 day intervals resulting in a final dilution of the reservoir solution with water in the ratio 1:8. In between, plates were stored at $20{ }^{\circ} \mathrm{C}$ in the dark.

\section{Second Order Nonlinear Imaging of Chiral Crystals (SONICC)}

The protein drops of the crystallization and dilution experiments were monitored at $20^{\circ} \mathrm{C}$ using the SONICC benchtop instrument (Formulatrix, USA). One 96-well plate at a time was imaged. Pictures were taken under visible light and in the SONICC imaging mode using the software Rock Imager and Rock Maker software implemented in the instrument. For SONICC imaging, the exposure time was $1000 \mathrm{~ms}$ and the power was $300 \mathrm{~mW}$.

\section{RESULTS}

In this study about 2000 protein crystallization conditions were tested using the vapordiffusion technique (sitting-drop method) followed by a dilution procedure to reverse the crystallizations conditions and investigate the effect on nanocrystals. Therefore, crystal growth was monitored by SONICC in combination with optical imaging. Afterward the reservoir solutions of the trials were diluted with water in three consecutive steps in intervals of 3 days. The crystallization drops were again monitored using the SONICC imaging system. Three different proteins were screened, the inner membrane protein CapA from $F$. tularensis attached to GFP (CapA-frGFP), the membrane-bound protein complex Photosystem I (PSI) from T. elongatus, and the soluble protein mGFPsol, a GFP variant. ${ }^{37,39-41}$ CapA-frGFP crystallization plates were incubated for 7 days, PSI plates for 9 days, and mGFPsol trials for 15 days. Immediately before each dilution step and 3 and 7 
days after the last dilution step, the drops were imaged (in the case of the mGFPsol experiment pictures were taken 5 and 11 days after the third dilution step). Figure 1 shows exemplary a set of results from the PSI experiments. At the first condition macrocrystals visible with the light microscope cause a strong SONICC signal. Dilution of the reservoir led to a dissolution of the crystals, and therefore the SONICC signal vanished (Figure 1A, conditions: $0.05 \mathrm{M}$ BIS-TRIS pH 6.5, $0.05 \mathrm{M}$ ammonium sulfate, $30 \% \mathrm{v} / \mathrm{v}$ Pentaerythritol ethoxylate $(15 / 4 \mathrm{EO} / \mathrm{OH}))$. The second example shows clear drops and no SONICC signal. It represents a negative control and demonstrates that proteins in solution do not lead to any SONICC signal (Figure 1B, conditions: 0.1 M BIS-TRIS pH 6.5, 2.0 M ammonium sulfate). The third example shows a drop that visualizes as precipitate in optical microscopy; however it shows a strong SONICC signal, indicating the presence of protein nanocrystals. After the dilution procedure the nanocrystals dissolved and the SONICC signal vanished (Figure 1C, conditions: $0.1 \mathrm{M}$ succinic acid $\mathrm{pH} 7.0,15 \% \mathrm{w} / \mathrm{v}$ polyethylene glycol 3,350). The fourth example shows precipitate, but no SONICC signal was detected; therefore, the precipitate consists of not ordered protein molecules. No dissolution of the precipitate was observed after the dilution procedure (Figure 1D, conditions: $0.2 \mathrm{M}$ potassium nitrate, $20 \% \mathrm{w} / \mathrm{v}$ polyethylene glycol 3,350, $\mathrm{pH} 6.8$ ). These examples are in agreement with the working hypothesis that precipitate consisting of nanocrystals dissolves after the dilution procedure, but aggregated protein does not. However, the fifth example shows precipitate which did not dissolve after the dilution procedure, but a positive SONICC signal was observed (Figure $1 \mathrm{E}$, conditions: $0.1 \mathrm{M}$ sodium acetate trihydrate $\mathrm{pH} 4.6,0.1 \mathrm{M}$ sodium chloride, $12 \% \mathrm{w} / \mathrm{v}$ polyethylene glycol 6,000). This example demonstrates that not all nanocrystals that were detected by SONICC dissolved during the dilution process. We hypothesize that the nonsaturated part of the phase diagram has not been reached under these conditions.

To examine the behavior of crystals and precipitates after the dilution procedure in general and detect possible trends the conditions for all three proteins were examined in a quantitative approach. For each drop at each condition, the observations before dilution were recorded and three cases were distinguished: (1) macrocrystals visible with the microscope, (2) precipitate, or (3) a clear drop. It was also recorded if a SONICC signal was detected or not. Additionally it was monitored for each condition if dissolution of the precipitate or crystal was observed after the third step of the dilution procedure. Table 1 shows the results in form of a general overview. In total 2112 conditions were tested (768 for CapA-frGFP, 768 for PSI and 576 for mGFPsol). The PSI crystallization experiments led to macrocrystals at 110 conditions ( 105 of them showed a positive SONICC signal) and mGFPsol formed macrocrystals at 267 conditions (all of them visible with SONICC). No macrocrystals were observed for CapA-frGFP at any conditions. However, it is very remarkable that 70\% (424 conditions out of 603) of the precipitates observed in the CapA-frGFP experiment showed a positive SONICC signal indicating protein nanocrystals. $83 \%$ of the precipitates for both the PSI experiment (288 conditions out of 346) and the mGFPsol experiment (163 conditions out of 196) showed a positive SONICC signal and therefore precipitate comprising nanocrystals. These numbers indicate that nanocrystals form much more easily than macrocrystals and that a high percentage of conditions contain valuable crystalline material, which is not detectable with optical microscopy. Remarkably $40 \%$ of the visually clear drops of the CapA-frGFP experiment (50 out of 125), 5\% of the visually clear drops of the PSI 
experiment (14 out of 298), and 96\% of the visually clear drops of the mGFPsol experiment (107 out of 111) show a positive SONICC signal. These drops appear clear in the brightfield pictures, but obviously contain nanocrystals detectable by SONICC. In these cases the concentration is too low to be visible as a precipitate, and individual nanocrystals are too small $(<1 \mu \mathrm{m})$ to be detectable with the bright-field microscope. These observations underline that nanocrystals are extremely frequently formed at several conditions in crystallization experiments, but has escaped detection with optical microscopy. Unsurprisingly the soluble protein forms nanocrystals at even more conditions than the hydrophobic membrane proteins, which crystallize in the form of protein detergent micelles.

In the CapA-frGFP experiment $16 \%$ of precipitate containing nanocrystals detected by SONICC dissolved after the dilution procedure (69 conditions out of 424). The same was observed in $57 \%$ of the cases in the PSI experiment (163 out of 288) and in $31 \%$ of the mGFPsol experiment (50 out of 163). This means that a high percentage of nanocrystals does not dissolve after the dilution procedure. Probably in these cases undersaturated conditions are not reached yet, and the nanocrystals are still stable. In several cases the SONICC signal did not significantly decrease or vanish during the dilution procedure (data not shown) indicating that nanocrystal concentration did not change at all or only in nondetectable amounts. 29\% of macrocrystals in the PSI experiment (30 out of 105) and $50 \%$ of macrocrystals of the mGFPsol experiment (134 out of 267) did not dissolve during the dilution process. Apparently the dilution procedure did not lead to the undersaturated state for these conditions either and the macrocrystals are still stable.

The fact that not all nanocrystals detected by SONICC dissolved after the dilution process led to the following question: Do all dissolving precipitates consist of nanocrystals? Table 2 gives an overview of the number of conditions where dissolution of precipitate was observed. For each protein and each crystal screen the total numbers of dissolving precipitate are listed. The cases are divided into conditions showing a SONICC signal or no SONICC signal prior to the dilution procedure. In 76 cases of the CapA-frGFP experiment dissolution of precipitate was observed, and in 67 of these cases a positive SONICC signal was detected. This means that $91 \%$ of the precipitate, which dissolved during the dilution procedure, contained nanocrystals. In 175 cases of the PSI experiment the precipitate solubilized, and in 163 of them a SONICC signal was detected prior to the dilution procedure. This means that $93 \%$ of the dissolving precipitates consist of nanocrystals. Precipitates, which dissolve but did not show any SONICC signal, may be either protein crystals in space groups, which are not detectable with SONICC, or salt crystals. It is known that some protein crystals in high symmetry classes do not produce any SONICC signal. Most of the salt crystals are not chiral and have a centrosymmetric space group and therefore do not show any SONICC signal..$^{30,32,33}$ However, the possibility cannot be ruled out that in these few cases the precipitate dissolves even though they do not contain any crystalline material. The dilution procedure applied to the mGFPsol crystallization trials led to dissolution of the precipitate at 50 conditions, and for all of them a positive SONICC signal was initially detected. Thus, for the soluble protein mGFPsol $100 \%$ of the dissolving precipitates contained indeed nanocrystals. 
Not all cases described in the previous paragraph showed a complete dissolution of the precipitate, and the SONICC signal did not fully disappear after the dilution procedure. Table 3 gives an overview of the detailed observations for all resolving precipitates. Numbers are given in percentage. Total numbers of conditions, which lead to a dissolving precipitate in the absence of any macrocrystals, were 76 for CapA-frGFP, 175 for PSI, and 50 mGFPsol (see Table 2). In Table 3 it is distinguished between complete and partly dissolution and monitored if the SONICC signal decreased, vanished, or was unchanged.

Complete dissolution of the precipitate and vanishing or decreasing of the SONICC signal indicates pure nanocrystals without any contamination of denatured protein (Figure 1C and Figure 2C, conditions for Figure 2C: mGFPsol in 0.1 M TRIS hydrochloride pH 8.5, 0.2 M lithium sulfate monohydrate, $30 \% \mathrm{w} / \mathrm{v}$ polyethylene glycol 4000 ). This was observed in $43 \%$ of the cases in the PSI experiments. Thereby complete dissolution but only decreasing of the SONICC signal indicates that a small amount of crystals detectable solely with SONICC still exists after the dilution process. This observation was also made in $66 \%$ of the cases in the mGFPsol experiment.

When the precipitate dissolves only partly and the SONICC signal decreases, precipitate may consist of pure nanocrystals, which do not dissolve completely (Figure 2A, conditions: CapA-frGFP in 0.1 M BIS-TRIS pH 6.5, 2.0 M ammonium sulfate). This was observed in $74 \%$ of the cases in the CapA-frGFP experiment and in $20 \%$ of the cases in the PSI and in the mGFPsol experiment. However, it cannot be excluded that the nondissolving residue is a mixture of nanocrystals and denatured protein. At $26 \%$ of the conditions in the PSI experiment the precipitate dissolved partly, and the SONICC signal intensity was unchanged (Figure 2B, conditions: 0.1 M Bis-Tris pH 6.5, 0.05 M calcium chloride dehydrate, 30\% v/v polyethylene glycol monomethyl ether 550). In these cases precipitate may be a nanocrystal/ aggregated protein mixture or nanocrystals do not dissolve completely, and differences in nanocrystal concentration may be too low to be detectable with SONICC. In less than $10 \%$ of the cases in each experiment partly dissolution of the precipitate was observed, and the SONICC signal vanished. At these conditions the precipitate contains nanocrystals but is apparently contaminated with aggregated protein.

\section{DISCUSSION}

In this study it was shown that nanocrystals can be identified based on the reversibility of crystallization. By reversing the crystallization conditions in a high-through put setup in 96well crystallization plates using a Rigaku crystallization robot, three different proteins were analyzed and >2000 conditions were screened in total. In $90 \%$ of the cases where dissolution of precipitate was observed nanocrystals were identified by SONICC. The dilution method allows screening for nanocrystals in every crystallization lab equipped with a crystallization robot and a common imaging system. No additional instrumentation and no additional treatment of the crystals are necessary. This is a valuable tool to detect potential conditions for nanocrystal growth and can be used as a complementary technique to the identification of nanocrystal by SONICC. The dilution method not only can be used when a SONICC system is not accessible but also is applicable to SONICC silent proteins. 
However, a lot of conditions with nanocrystalline material are not detected with the dilution procedure. Screening the crystallization experiments with SONICC showed that a much higher percentage of precipitate and also clear drops contain nanocrystals. Some of these precipitates may be only partly crystalline and also contain aggregated proteins. For other conditions the undersaturated state is probably not reached upon the dilution process, and nanocrystals are still stable. In general, the experiments show that many conditions contain valuable crystalline material, which is not accessible with common techniques in crystallography.

The data reveal that the dissolution behavior of the precipitates depends on the protein preparation and the crystallization conditions. In many cases complete dissolution of the precipitate and in other cases only partly solution were observed. Complete dissolution indicates pure nanocrystals, whereas in the case of partly dissolution contamination with denatured protein cannot be ruled out. In the PSI experiment four Hampton Research HT crystallization screens were tested and complete dissolution of precipitate was observed at 76 conditions (43\% of all dissolving precipitates). The protein mGFPsol was screened with three crystallization screens, and at 35 conditions complete dissolution of precipitate was observed (70\% of all dissolving precipitates). Only for the CapA-frGFP preparation complete dissolution was not observed at any condition.

For detection of precipitate a bright-field imaging based detection method was used, which is present in nearly every crystallization laboratory. Pictures were classified manually to identify precipitate prior to the dilution procedure and a clear drop afterward. However, bright-field imaged based crystal detection has already been computerized. ${ }^{42,43}$ Classification systems determine precipitates with a success rate of $89 \%$ and clear drops with a success rate of $98 \% .{ }^{43}$ Combining the automated dilution procedure with a computerized scoring system would facilitate screening for nanocrystals and save the researcher valuable time.

Once promising conditions are identified further characterization by methods as dynamic light scattering and powder X-ray diffraction are necessary to ensure high quality sample preparations for structural analysis with X-ray free electron laser. Detected conditions can be also useful for finding optimized sample preparation protocols for structure determination with solid-state NMR spectroscopy.

\section{Acknowledgments}

Funding

The work was supported by the National Institutes of Health (U54 GM094599 (PSI:Biology center for membrane proteins in infectious diseases to P.F., R.W.) and the grant (GM095583 to P.F.) as well as the U.S. National Science Foundation Science and Technology Center BioXFEL Award 1231306 (P.F.). C.K. was supported by the National Science Foundation Grant MCB-1021557. Part of the work was supported by the European Research Council under the European Union's 7th framework program ERC Synergy Grant 609920, AXSIS. 


\section{References}

1. Rasmussen SG, Choi HJ, Rosenbaum DM, Kobilka TS, Thian FS, Edwards PC, Burghammer M, Ratnala VR, Sanishvili R, Fischetti RF, Schertler GF, Weis WI, Kobilka BK. Nature. 2007; 450:383. [PubMed: 17952055]

2. Warne T, Serrano-Vega MJ, Baker JG, Moukhametzianov R, Edwards PC, Henderson R, Leslie AG, Tate CG, Schertler GF. Nature. 2008; 454:486. [PubMed: 18594507]

3. Smith JL, Fischetti RF, Yamamoto M. Curr Opin Struct Biol. 2012; 22:602. [PubMed: 23021872]

4. Chapman HN, Fromme P, Barty A, White TA, Kirian RA, Aquila A, Hunter MS, Schulz J, DePonte DP, Weierstall U, Doak RB, Maia FR, Martin AV, Schlichting I, Lomb L, Coppola N, Shoeman RL, Epp SW, Hartmann R, Rolles D, Rudenko A, Foucar L, Kimmel N, Weidenspointner G, Holl P, Liang M, Barthelmess M, Caleman C, Boutet S, Bogan MJ, Krzywinski J, Bostedt C, Bajt S, Gumprecht L, Rudek B, Erk B, Schmidt C, Homke A, Reich C, Pietschner D, Struder L, Hauser G, Gorke H, Ullrich J, Herrmann S, Schaller G, Schopper F, Soltau H, Kuhnel KU, Messerschmidt M, Bozek JD, Hau-Riege SP, Frank M, Hampton CY, Sierra RG, Starodub D, Williams GJ, Hajdu J, Timneanu N, Seibert MM, Andreasson J, Rocker A, Jonsson O, Svenda M, Stern S, Nass K, Andritschke R, Schroter CD, Krasniqi F, Bott M, Schmidt KE, Wang X, Grotjohann I, Holton JM, Barends TR, Neutze R, Marchesini S, Fromme R, Schorb S, Rupp D, Adolph M, Gorkhover T, Andersson I, Hirsemann H, Potdevin G, Graafsma H, Nilsson B, Spence JC. Nature. 2011; 470:73. [PubMed: 21293373]

5. Kirian RA, White TA, Holton JM, Chapman HN, Fromme P, Barty A, Lomb L, Aquila A, Maia FR, Martin AV, Fromme R, Wang X, Hunter MS, Schmidt KE, Spence JC. Acta Crystallogr Sect A: Found Crystallogr. 2011; 67:131.

6. Boutet S, Lomb L, Williams GJ, Barends TR, Aquila A, Doak RB, Weierstall U, DePonte DP, Steinbrener J, Shoeman RL, Messerschmidt M, Barty A, White TA, Kassemeyer S, Kirian RA, Seibert MM, Montanez PA, Kenney C, Herbst R, Hart P, Pines J, Haller G, Gruner SM, Philipp HT, Tate MW, Hromalik M, Koerner LJ, van Bakel N, Morse J, Ghonsalves W, Arnlund D, Bogan MJ, Caleman C, Fromme R, Hampton CY, Hunter MS, Johansson LC, Katona G, Kupitz C, Liang M, Martin AV, Nass K, Redecke L, Stellato F, Timneanu N, Wang D, Zatsepin NA, Schafer D, Defever J, Neutze R, Fromme P, Spence JC, Chapman HN, Schlichting I. Science. 2012; 337:362. [PubMed: 22653729]

7. Redecke L, Nass K, DePonte DP, White TA, Rehders D, Barty A, Stellato F, Liang M, Barends TR, Boutet S, Williams GJ, Messerschmidt M, Seibert MM, Aquila A, Arnlund D, Bajt S, Barth T, Bogan MJ, Caleman C, Chao TC, Doak RB, Fleckenstein H, Frank M, Fromme R, Galli L, Grotjohann I, Hunter MS, Johansson LC, Kassemeyer S, Katona G, Kirian RA, Koopmann R, Kupitz C, Lomb L, Martin AV, Mogk S, Neutze R, Shoeman RL, Steinbrener J, Timneanu N, Wang D, Weierstall U, Zatsepin NA, Spence JC, Fromme P, Schlichting I, Duszenko M, Betzel C, Chapman HN. Science. 2013; 339:227. [PubMed: 23196907]

8. Ayyer K, Yefanov OM, Oberthur D, Roy-Chowdhury S, Galli L, Mariani V, Basu S, Coe J, Conrad CE, Fromme R, Schaffer A, Dorner K, James D, Kupitz C, Metz M, Nelson G, Xavier PL, Beyerlein KR, Schmidt M, Sarrou I, Spence JC, Weierstall U, White TA, Yang JH, Zhao Y, Liang M, Aquila A, Hunter MS, Robinson JS, Koglin JE, Boutet S, Fromme P, Barty A, Chapman HN. Nature. 2016; 530:202. [PubMed: 26863980]

9. Caffrey M. J Struct Biol. 2003; 142:108. [PubMed: 12718924]

10. Fromme P, Spence JC. Curr Opin Struct Biol. 2011; 21:509. [PubMed: 21752635]

11. White, S. 2014. http://blanco.biomol.uci.edu/mpstruc/

12. Yildirim MA, Goh KI, Cusick ME, Barabasi AL, Vidal M. Nat Biotechnol. 2007; 25:1119. [PubMed: 17921997]

13. Stevens TJ, Arkin IT. Proteins: Struct Funct Genet. 2000; 39:417. [PubMed: 10813823]

14. Krogh A, Larsson B, von Heijne G, Sonnhammer EL. J Mol Biol. 2001; 305:567. [PubMed: 11152613]

15. Aquila A, Hunter MS, Doak RB, Kirian RA, Fromme P, White TA, Andreasson J, Arnlund D, Bajt S, Barends TR, Barthelmess M, Bogan MJ, Bostedt C, Bottin H, Bozek JD, Caleman C, Coppola N, Davidsson J, DePonte DP, Elser V, Epp SW, Erk B, Fleckenstein H, Foucar L, Frank M, Fromme R, Graafsma H, Grotjohann I, Gumprecht L, Hajdu J, Hampton CY, Hartmann A, 
Hartmann R, Hau-Riege S, Hauser G, Hirsemann H, Holl P, Holton JM, Homke A, Johansson L, Kimmel N, Kassemeyer S, Krasniqi F, Kuhnel KU, Liang M, Lomb L, Malmerberg E, Marchesini S, Martin AV, Maia FR, Messerschmidt M, Nass K, Reich C, Neutze R, Rolles D, Rudek B, Rudenko A, Schlichting I, Schmidt C, Schmidt KE, Schulz J, Seibert MM, Shoeman RL, Sierra R, Soltau H, Starodub D, Stellato F, Stern S, Struder L, Timneanu N, Ullrich J, Wang X, Williams GJ, Weidenspointner G, Weierstall U, Wunderer C, Barty A, Spence JC, Chapman HN. Opt Express. 2012; 20:2706. [PubMed: 22330507]

16. Spence JC, Weierstall U, Chapman HN. Rep Prog Phys. 2012; 75:102601. [PubMed: 22975810]

17. Kupitz C, Basu S, Grotjohann I, Fromme R, Zatsepin NA, Rendek KN, Hunter MS, Shoeman RL, White TA, Wang D, James D, Yang JH, Cobb DE, Reeder B, Sierra RG, Liu H, Barty A, Aquila AL, Deponte D, Kirian RA, Bari S, Bergkamp JJ, Beyerlein KR, Bogan MJ, Caleman C, Chao TC, Conrad CE, Davis KM, Fleckenstein H, Galli L, Hau-Riege SP, Kassemeyer S, Laksmono H, Liang M, Lomb L, Marchesini S, Martin AV, Messerschmidt M, Milathianaki D, Nass K, Ros A, Roy-Chowdhury S, Schmidt K, Seibert M, Steinbrener J, Stellato F, Yan L, Yoon C, Moore TA, Moore AL, Pushkar Y, Williams GJ, Boutet S, Doak RB, Weierstall U, Frank M, Chapman HN, Spence JC, Fromme P. Nature. 2014; 513:261. [PubMed: 25043005]

18. Tenboer J, Basu S, Zatsepin N, Pande K, Milathianaki D, Frank M, Hunter M, Boutet S, Williams GJ, Koglin JE, Oberthuer D, Heymann M, Kupitz C, Conrad C, Coe J, RoyChowdhury S, Weierstall U, James D, Wang D, Grant T, Barty A, Yefanov O, Scales J, Gati C, Seuring C, Srajer V, Henning R, Schwander P, Fromme R, Ourmazd A, Moffat K, Van Thor JJ, Spence JC, Fromme P, Chapman HN, Schmidt M. Science. 2014; 346:1242. [PubMed: 25477465]

19. Barty A, Caleman C, Aquila A, Timneanu N, Lomb L, White TA, Andreasson J, Arnlund D, Bajt S, Barends TR, Barthelmess M, Bogan MJ, Bostedt C, Bozek JD, Coffee R, Coppola N, Davidsson J, Deponte DP, Doak RB, Ekeberg T, Elser V, Epp SW, Erk B, Fleckenstein H, Foucar L, Fromme P, Graafsma H, Gumprecht L, Hajdu J, Hampton CY, Hartmann R, Hartmann A, Hauser G, Hirsemann H, Holl P, Hunter MS, Johansson L, Kassemeyer S, Kimmel N, Kirian RA, Liang M, Maia FR, Malmerberg E, Marchesini S, Martin AV, Nass K, Neutze R, Reich C, Rolles D, Rudek B, Rudenko A, Scott H, Schlichting I, Schulz J, Seibert MM, Shoeman RL, Sierra RG, Soltau H, Spence JC, Stellato F, Stern S, Struder L, Ullrich J, Wang X, Weidenspointner G, Weierstall U, Wunderer CB, Chapman HN. Nat Photonics. 2012; 6:35. [PubMed: 24078834]

20. Neutze R, Wouts R, van der Spoel D, Weckert E, Hajdu J. Nature. 2000; 406:752. [PubMed: 10963603]

21. Barends TRM, Foucar L, Ardevol A, Nass K, Aquila A, Botha S, Doak RB, Falahati K, Hartmann E, Hilpert M, Heinz M, Hoffmann MC, Kofinger J, Koglin JE, Kovacsova G, Liang M, Milathianaki D, Lemke HT, Reinstein J, Roome CM, Shoeman RL, Williams GJ, Burghardt I, Hummer G, Boutet S, Schlichting I. Science. 2015; 350:445. [PubMed: 26359336]

22. Von Dreele RB. J Appl Crystallogr. 2007; 40:133.

23. Chen JP, Millane RP. J Opt Soc Am A. 2013; 30:2627.

24. Dilanian RA, Streltsov VA, Quiney HM, Nugent KA. Acta Crystallogr Sect A: Found Crystallogr. 2013; 69:108.

25. Bockmann A, Lange A, Galinier A, Luca S, Giraud N, Juy M, Heise H, Montserret R, Penin F, Baldus M. J Biomol NMR. 2003; 27:323. [PubMed: 14512730]

26. Martin RW, Zilm KW. J Magn Reson. 2003; 165:162. [PubMed: 14568526]

27. Lorch M, Faham S, Kaiser C, Weber I, Mason AJ, Bowie JU, Glaubitz C. ChemBioChem. 2005; 6:1693. [PubMed: 16138309]

28. Shahid SA, Bardiaux B, Franks WT, Krabben L, Habeck M, van Rossum BJ, Linke D. Nat Methods. 2012; 9:1212. [PubMed: 23142870]

29. Wampler RD, Kissick DJ, Dehen CJ, Gualtieri EJ, Grey JL, Wang HF, Thompson DH, Cheng JX, Simpson GJ. J Am Chem Soc. 2008; 130:14076. [PubMed: 18831587]

30. Haupert LM, Simpson G. J Methods. 2011; 55:379.

31. Reeve JE, Anderson HL, Clays K. Phys Chem Chem Phys. 2010; 12:13484. [PubMed: 20820473]

32. Closser RG, Gualtieri EJ, Newman JA, Simpson GJ. J Appl Crystallogr. 2013; 46:1903. [PubMed: 24282335] 
33. Haupert LM, DeWalt EL, Simpson GJ. Acta Crystallogr Sect D: Biol Crystallogr. 2012; 68:1513. [PubMed: 23090400]

34. Campagnola PJ, Millard AC, Terasaki M, Hoppe PE, Malone CJ, Mohler WA. Biophys J. 2002; 82:493. [PubMed: 11751336]

35. Millard AC, Campagnola PJ, Mohler W, Lewis A, Loew LM. Methods Enzymol. 2003; 361:47. [PubMed: 12624906]

36. Hirata, KKY., Ueno, G., Hashimoto, K., Murakami, H., Hasegawa, K., Hikima, T., Kumasaka, T., Yamamoto, M., Kawano, Y. J Phys: Conf Ser. 2013. Conference Series425012002.10.1088/1742-6596/425/1/012002

37. Fromme P, Witt HT. Biochim Biophys Acta, Bioenerg. 1998; 1365:175.

38. Jordan P, Fromme P, Witt HT, Klukas O, Saenger W, Krauss N. Nature. 2001; 411:909. [PubMed: 11418848]

39. Martin-Garcia JM, Hansen DT, Zook J, Loskutov AV, Robida MD, Craciunescu FM, Sykes KF, Wachter RM, Fromme P, Allen JP. Biochemistry. 2014; 53:1958. [PubMed: 24593131]

40. Pouwels LJ, Zhang L, Chan NH, Dorrestein PC, Wachter RM. Biochemistry. 2008; 47:10111. [PubMed: 18759496]

41. Zhang L, Patel HN, Lappe JW, Wachter RM. J Am Chem Soc. 2006; 128:4766. [PubMed: 16594713]

42. Liu R, Freund Y, Spraggon G. Acta Crystallogr Sect D: Biol Crystallogr. 2008; 64:1187. [PubMed: 19018095]

43. Cumbaa CA, Jurisica I. J Struct Funct Genomics. 2010; 11:61. [PubMed: 20072819] 


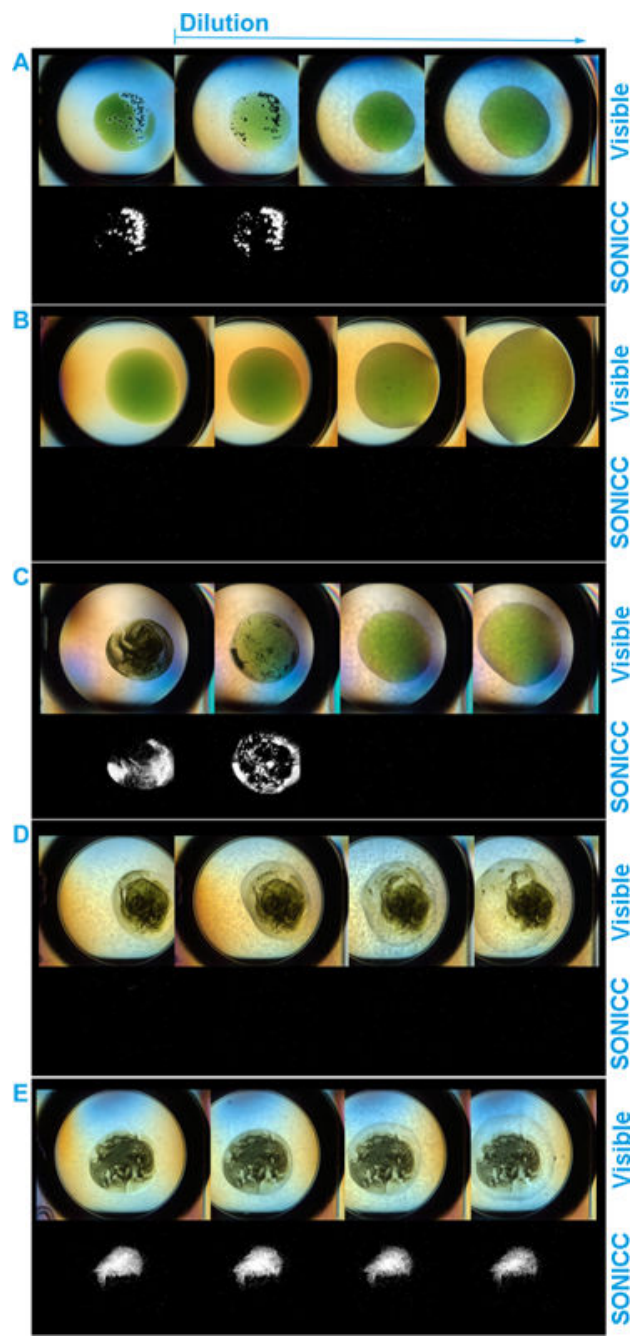

Figure 1.

Bright-field and SONICC pictures of five different conditions of the PSI experiment. Pictures of the drops were taken directly before each of the three dilution steps and 6 days after the last dilution step. (A) Macrocrystals with a strong SONICC signal dissolve upon dilution. (B) Clear drops without any nanocrystals (negative SONICC). (C) Precipitate consisting of nanocrystals (positive SONICC) dissolves during the dilution procedure. (D) Precipitates consisting of aggregated protein (no SONICC) do not dissolve. (E) Nanocrystals (positive SONICC) do not dissolve during the dilution process. 

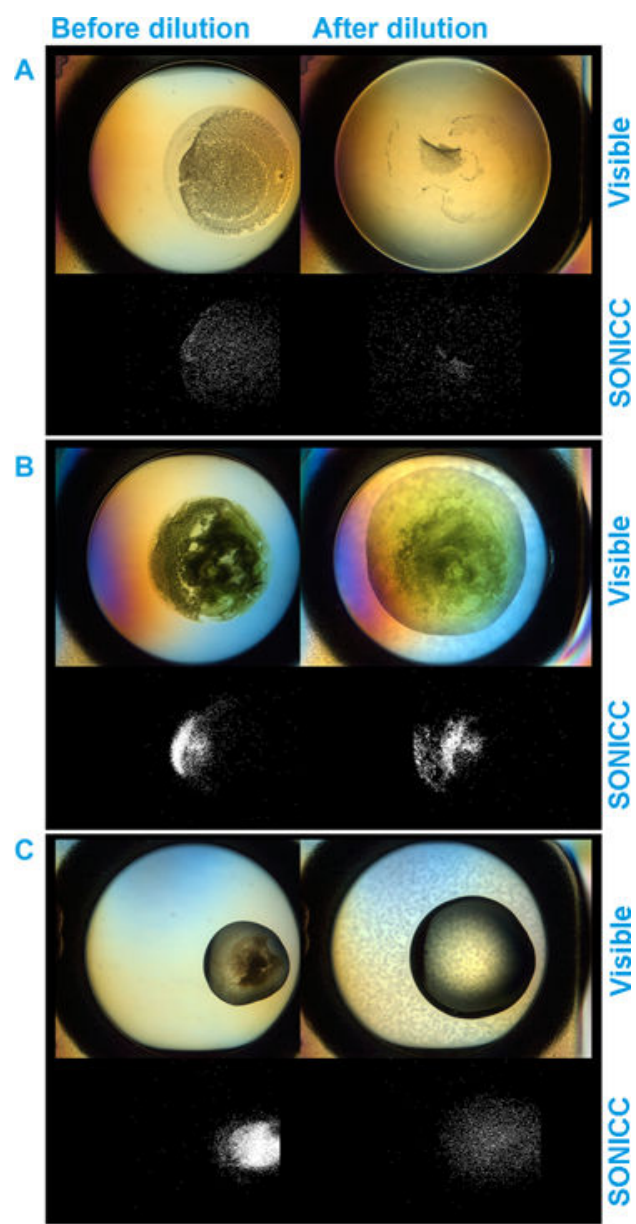

Figure 2.

Examples of dissolving precipitates. For each condition the bright-field and the SONICC pictures are shown before and after the dilution procedure. (A) Precipitate in the CapAfrGFP experiment dissolved not completely and the SONICC signal decreased. (B) Precipitate of the PSI experiment partly dissolved, and the intensity of the SONICC signal was unchanged. (C) Dissolving precipitate of the mGFPsol experiment results in a clear drop, and the SONICC signal intensity is only diminished. 


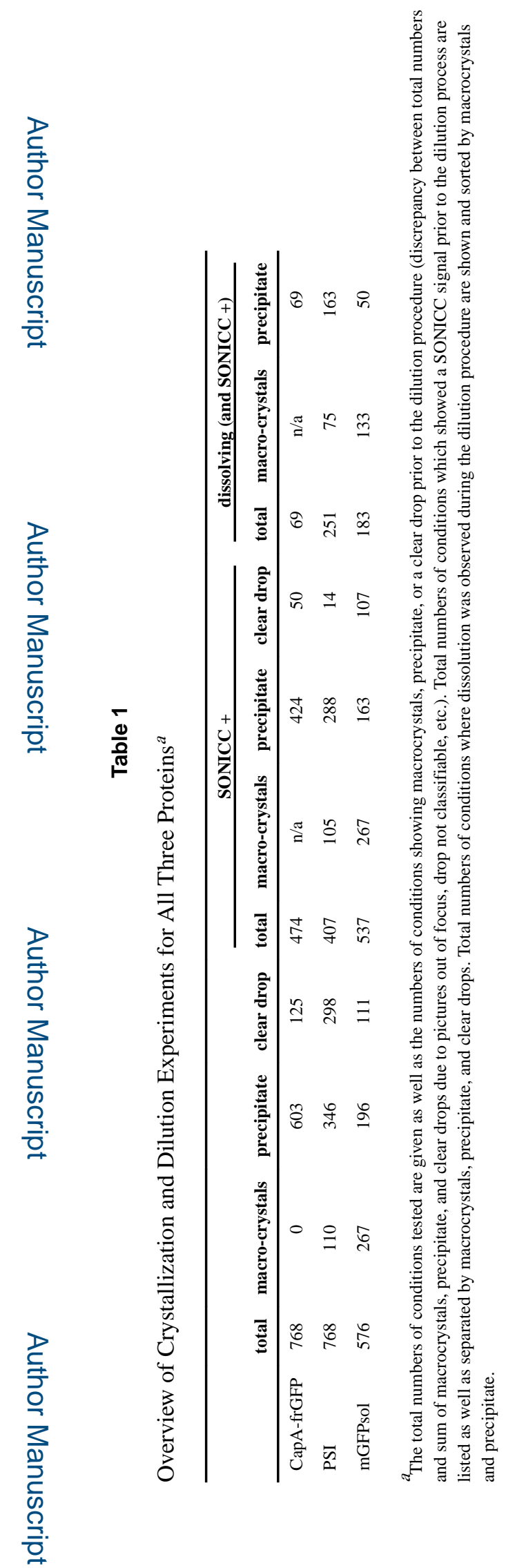

Cryst Growth Des. Author manuscript; available in PMC 2017 October 20. 


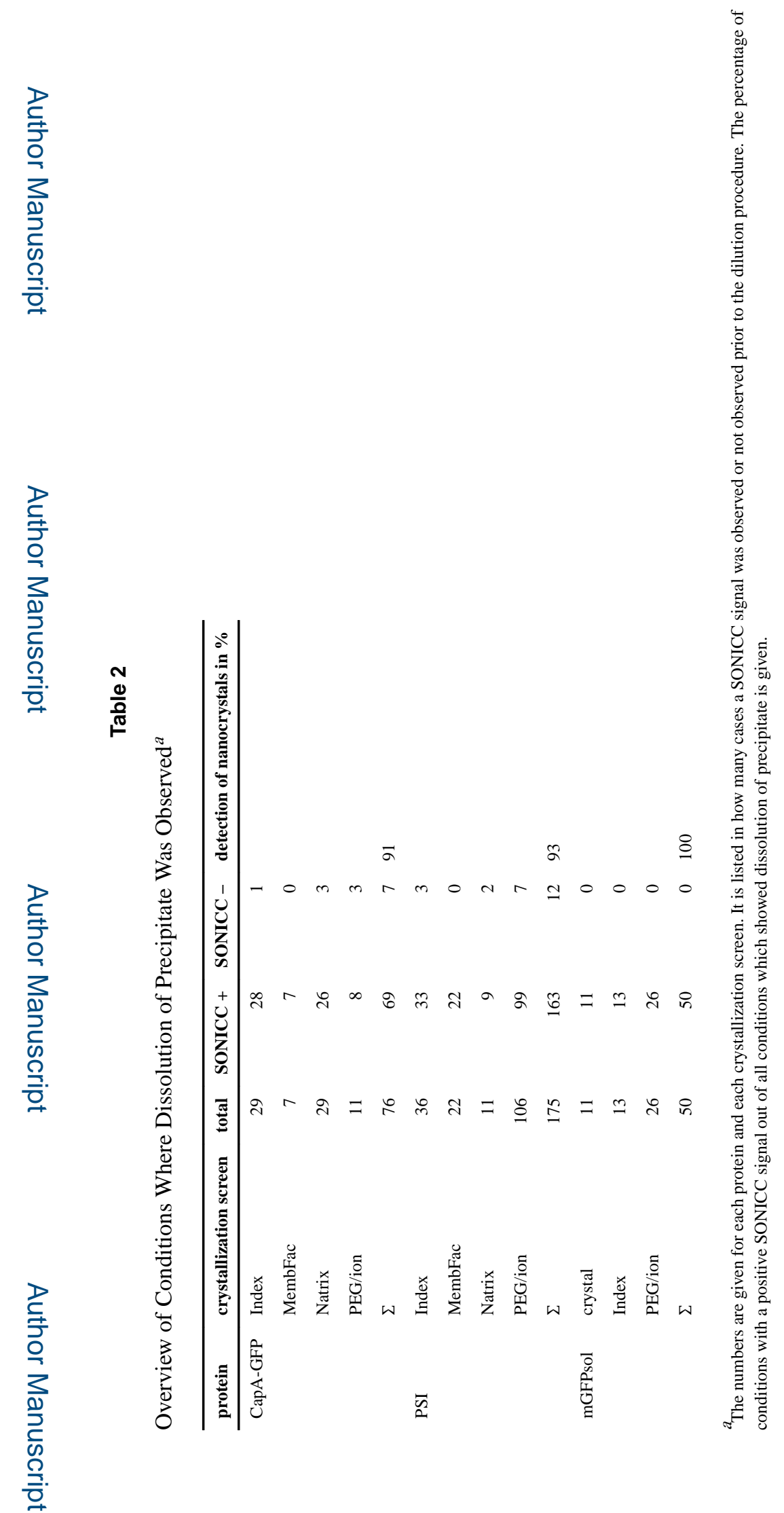



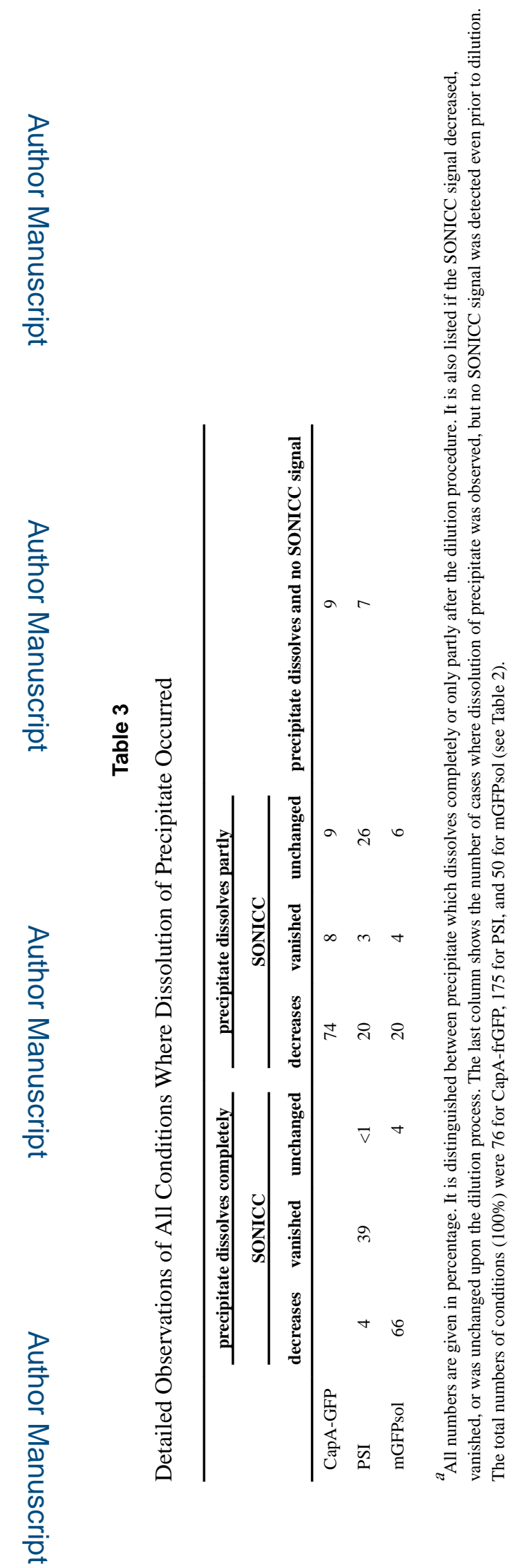

Cryst Growth Des. Author manuscript; available in PMC 2017 October 20. 